\title{
Localization and estrogenic regulation of androgen receptor mRNA expression in the mouse uterus and vagina
}

\author{
G Pelletier, V Luu-The, S Li and F Labrie \\ Atlas Project, Oncology and Molecular Endocrinology Research Center, Centre de Recherche du Centre Hospitalier de l'Université Laval (CRCHUL), Québec, \\ Québec G1 V 4 G2, Canada \\ (Requests for offprints should be addressed to G Pelletier, Oncology and Molecular Endocrinology Research Center, Le Centre Hospitalier de l'Université Laval \\ (CHUL), 2705, Laurier Boulevard, Quebec, Quebec G1 V 4 G2, Canada; Email: georges.pelletier@crchul.ulaval.ca)
}

\begin{abstract}
Androgen receptors (AR) are highly expressed in female reproductive organs. In order to define the possible involvement of estrogens in the regulation of AR expression in the uterus and vagina, we have studied the effect of short-term administration of $17 \beta$-estradiol $\left(\mathrm{E}_{2}\right)$ to ovariectomized adult mice on AR mRNA levels. Seven days after ovariectomy, the mice received a single injection of $\mathrm{E}_{2}$ ( $0.05 \mu \mathrm{g} /$ mouse) 3,12 or $24 \mathrm{~h}$ before they were killed. The levels of AR mRNA were measured in the different uterine and vaginal compartments using quantitative in situ hybridization. In the uterus, AR mRNA was expressed in the luminal and glandular epithelial cells, stromal cells and smooth muscle cells. In the vagina, AR mRNA was localized in both epithelial and stromal cells. In the uterus after ovariectomy, AR mRNA levels were decreased by $18 \%$ in the epithelial cells, $23 \%$ in the stromal cells and $50 \%$ in the myometrial cells. AR mRNA levels were completely restored as early as $3 \mathrm{~h}$ after $\mathrm{E}_{2}$ administration
\end{abstract}

in the epithelium and stroma, and at the 12-h timeinterval in the myometrium. In the vaginal epithelium, ovariectomy induced a $70 \%$ decrease in AR mRNA expression. No effect could be detected $3 \mathrm{~h}$ after $\mathrm{E}_{2}$ administration, while at the longest time-intervals (12 and $24 \mathrm{~h}$ ) there was an increase in mRNA levels corresponding to $70 \%$ of the levels observed in intact animals. In the vaginal stroma, ovariectomy was responsible for a 55\% decrease in mRNA levels. While no significant changes were observed at the 3-h time-interval, a complete restoration of AR mRNA levels in stromal cells could be recorded at the longest time-intervals after $\mathrm{E}_{2}$ administration. The data obtained indicated that, in adult mice, estrogens exert a positive regulation of AR mRNA expression in the different compartments of both the uterus and the vagina.

Journal of Endocrinology (2004) 180, 77-85

\section{Introduction}

Androgens play a predominant role in the development and physiological function of male accessory sex organs as well as the functioning of several other organs and tissues in both sexes (Carson-Jurica et al. 1990, Clark et al. 1992). The action of androgens is mediated by androgen receptors (AR) which belong to the superfamily of ligandresponsive transcription regulators (Evans 1988, CarsonJurica et al. 1990). By immunocytochemistry and in situ hybridization, AR has been found to be expressed in a large variety of tissues, including male and female reproductive organs (Ruizeveld de Winter et al. 1991, Kimura et al. 1993, Tetsuka et al. 1995, Adesanya-Famuyiwa et al. 1999, Pelletier 2000, Pelletier et al. 2000). In the rat uterus, AR has been localized by both immunocytochemistry and in situ hybridization in the epithelial, stromal and smooth muscle cells (Hirai et al. 1994, Pelletier 2000). Similar results have been reported in the human and monkey uterus (Kimura et al. 1993, Adesanya-
Famuyiwa et al. 1999, Pelletier 2000). In the human vagina, AR immunoreactivity was found in nuclei of both epithelial and stromal cells (Hodgins et al. 1998, Pelletier 2000). In the mouse, the localization of AR in female reproductive organs has not so far been reported.

Very little is known about the physiological role of androgens and the regulation of $A R$ in the uterus and vagina. In immature hypophysectomized rats, Armstrong \& Papkoff (1976) have shown that administration of testosterone or dihydrotestosterone induced an increase in uterine weight. In the ovariectomized monkey, a 3-day estradiol $\left(\mathrm{E}_{2}\right)$ treatment was shown to increase AR mRNA levels in uterine stromal cells (AdesanyaFamuyiwa et al. 1999). It has also been reported that estrogens can induce AR expression in the chick oviduct magnum mucosa (Tokarz et al. 1979). In order to further define the role of estrogens in the regulation of $A R$ expression, we have studied the effects of short-term $E_{2}$ administration to ovariectomized adult mice on uterine and vaginal AR mRNA levels using in situ hybridization. 

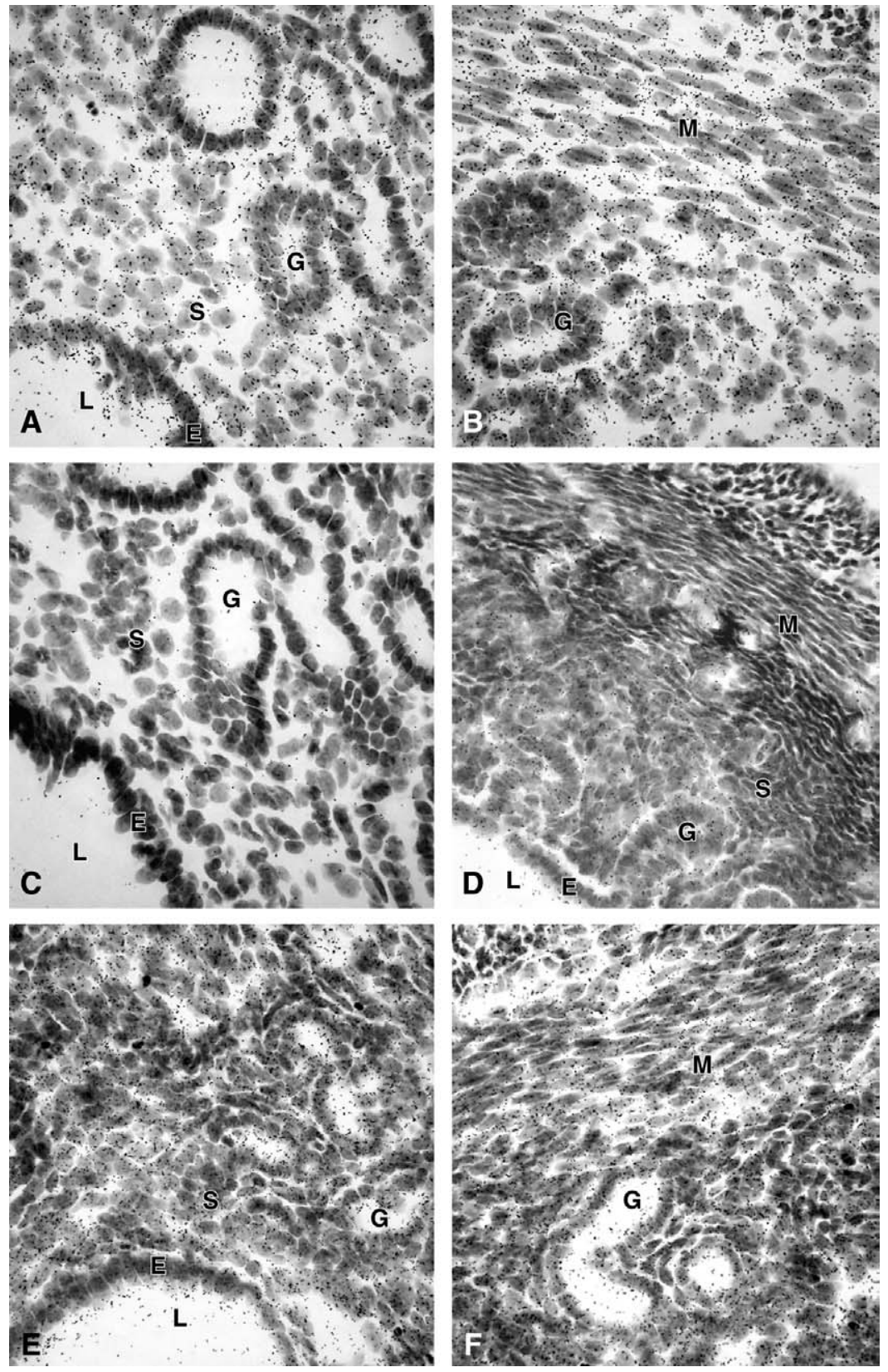

Figure 1 Representative brightfield micrographs illustrating the localization of AR mRNA in the mouse uterus after hybridization with the antisense riboprobe. (A and B) Intact mouse. (C) Section consecutive to that shown in (A) hybridized with the sense probe (negative control). (D) Ovariectomized mice. (E and F) Ovariectomized mice which received a single injection of $\mathrm{E}_{2} 24 \mathrm{~h}$ before they were killed. L: lumen; $\mathrm{E}$ : epithelial luminal cells; G: glands; S: stroma; M: myometrium $(\times 450)$.

\section{Materials and Methods}

\section{Animals and treatment}

Eleven- to twelve-week-old female C57BL6 mice were received from Charles River (St Constant, Quebec,
Canada) and were allowed to acclimate for 3 weeks. The animals were housed individually under constant temperature $\left(22 \pm 3{ }^{\circ} \mathrm{C}\right)$ and light (lights on from 0600 to $2000 \mathrm{~h})$ regimens. The mice had free access to tap water and a certified rodent feed (Lab Diet 5002 (pellet); 

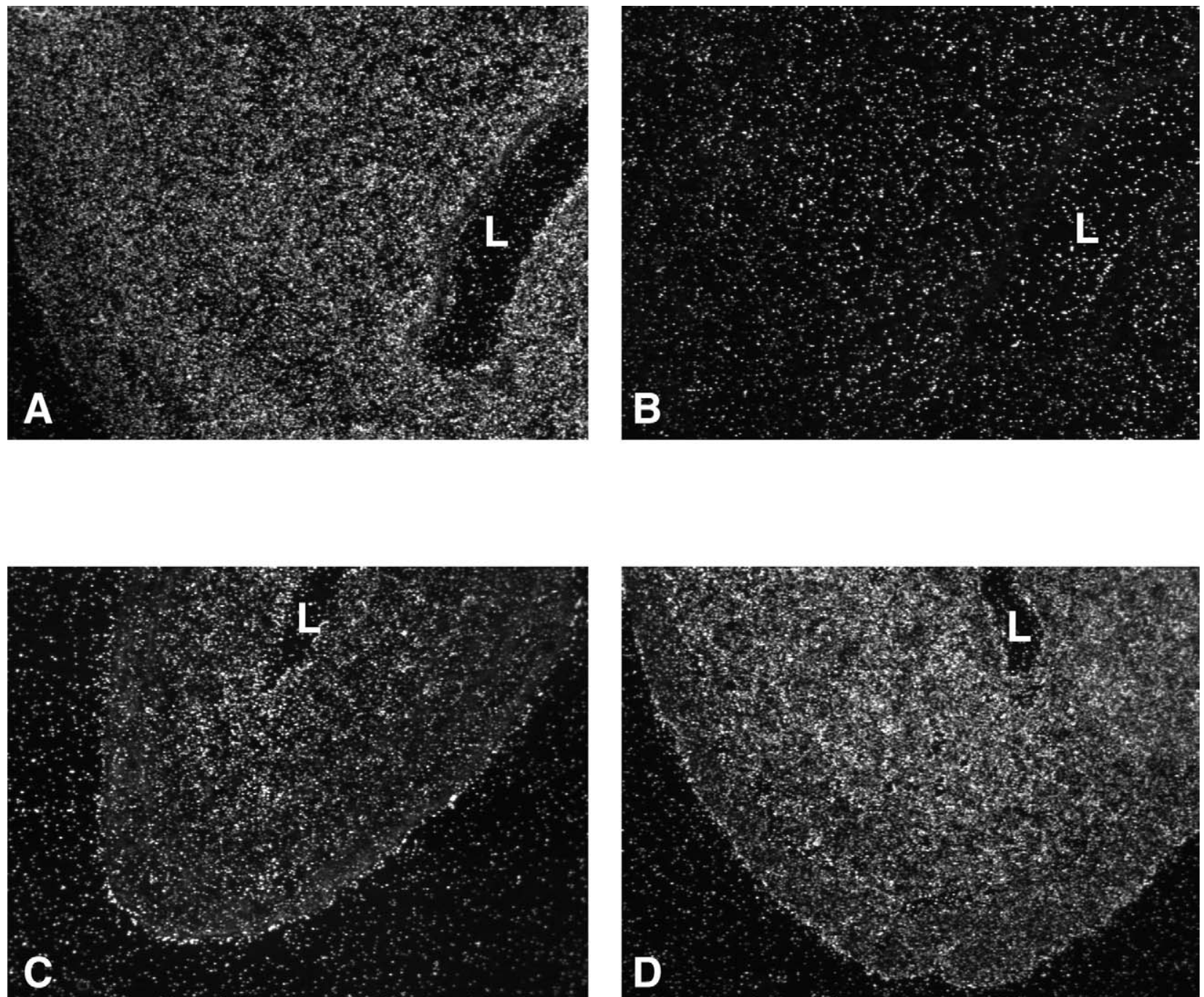

Figure 2 Representative darkfield micrographs illustrating AR mRNA hybridization signal in the mouse uterus. (A) Intact mice. (B) Section consecutive to that shown in (A) hybridized with the sense riboprobe (negative control). (C) Ovariectomized mice. (D) Ovariectomized mice which received a single injection of $E_{2} 24 \mathrm{~h}$ before they were killed. L: lumen $(\times 11)$.

Ralston Purina, St Louis, MO, USA). The experiment was conducted in an animal facility approved by the Canadian Council on Animal Care (CCAC) and the Association for Assessment and Accreditation of Laboratory Animal Care. The study was performed in accordance with the CCAC Guide for Care and Use of Experimental Animals.

Animals, weighing between 23 and 26 g were randomized according to their body weights and were assigned to five groups of five animals each as follows: (1) intact control; (2) ovariectomized control; (3-5) ovariectomized $+E_{2}(0.05 \mu \mathrm{g} / \mathrm{mouse})$. On day 1 of the study, animals of groups 2 to 5 were bilaterally ovariectomized under isoflurane anesthesia. Mice of group 1 were sham-operated (intact). Before the animals were killed on day 8 of the study, they received a single subcutaneous injection $(0 \cdot 2 \mathrm{ml} / \mathrm{mouse})$ of the vehicle alone $(5 \%$ ethanol- $-0 \cdot 4 \%$ methylcellulose; groups 1 and 2) or $\mathrm{E}_{2}$ (groups 3-5). The injection was performed $3 \mathrm{~h}$ (group 3), $12 \mathrm{~h}$ (group 4) or $24 \mathrm{~h}$ (groups 1, 2 and 5) before the animals were killed.

\section{Tissue collection}

On day 8 of the study, mice were anesthetized with ketamine/xylazine and perfused transcardially with $90 \mathrm{ml}$ $4 \%(\mathrm{w} / \mathrm{v})$ paraformaldehyde in $0.1 \mathrm{M}$ phosphate buffer $(\mathrm{pH} 7 \cdot 4)$. Prior to the perfusion, a vaginal smear was collected from intact female mice of group 1 in order to determine the estrous cycle using Papanicolaou staining. Mice in estrus were selected. The uterus and vagina were 
excised and post-fixed in the same fixative for $24 \mathrm{~h}$ at $4{ }^{\circ} \mathrm{C}$. The tissues were placed in $15 \%$ sucrose in $0 \cdot 1 \mathrm{M}$ phosphate buffer before being quickly frozen in isopentane chilled in liquid nitrogen.

\section{In situ hybridization}

Frozen sections $\left(10 \mu \mathrm{m}\right.$ thick) were serially cut at $-20{ }^{\circ} \mathrm{C}$ and mounted onto gelatin- and poly-L-lysine-coated slides. The vector used for production of the cRNA probe was constructed by insertion into a pCR-Blunt II-TOPO (Invitrogen, Ontario, Canada) of a cDNA fragment of 249 $\mathrm{pb}$ mouse AR (Genebank no. NM-013476). The cDNA fragment located at position 26-275 downstream from the ATG start codon was obtained by amplification using polymerase chain reaction. In situ hybridization with the antisense and sense ${ }^{35} \mathrm{~S}$-labeled cRNA probes was performed as previously described (Givalois et al. 1997). Briefly, the sections were prehybridized at room temperature in a humid chamber for $2 \mathrm{~h}$ in $450 \mu \mathrm{l} /$ slide of a prehybridization buffer containing 50\% formamide, $5 \times \mathrm{SSPE} \quad(1 \times \mathrm{SSPE}$ being $0.1 \mathrm{M} \quad \mathrm{NaCl}, \quad 10 \mathrm{mM}$ $\mathrm{NaH}_{2} \mathrm{PO}_{4}, \quad \mathrm{pH} \quad 7 \cdot 4, \quad \mathrm{mM} \quad$ EDTA), $5 \times$ Denhart's buffer, $200 \mathrm{mg} / \mathrm{ml}$ denatured salmon testis DNA (Sigma, St Louis, MO, USA), $200 \mu \mathrm{g} / \mathrm{ml}$ yeast tRNA, $2 \mu \mathrm{g} / \mathrm{ml}$ Poly A (Boehringer-Mannheim, Montreal, Canada) and $4 \%$ dextran sulphate. After the prehybridization procedure, a $100 \mu \mathrm{l}$ hybridization mixture (prehybridization buffer containing $10 \mathrm{nM}$ dithiothreitol and the ${ }^{35} \mathrm{~S}$-labeled cRNA probe at a concentration of $10 \times 10^{6}$ c.p.m./ml) was spotted on each slide, sealed under a coverslip and incubated at $37^{\circ} \mathrm{C}$ overnight $(15-20 \mathrm{~h})$ in a humid chamber.

After hybridization, coverslips were removed and slides were rinsed in $2 \times \mathrm{SSC}$ at room temperature for $30 \mathrm{~min}$. Sections were digested by RNase A $(20 \mu \mathrm{g} / \mathrm{ml}$ in $2 \times \mathrm{SSC})$ at $37^{\circ} \mathrm{C}$ for $30 \mathrm{~min}$ at room temperature, washed in $0.5 \times \mathrm{SSC}$ for $30 \mathrm{~min}$ at $37^{\circ} \mathrm{C}$, followed by $90 \mathrm{~min}$ at room temperature in $0.5 \times \mathrm{SSC}$, at $60^{\circ} \mathrm{C}$ in $0 \cdot 1 \times$ SSC and finally for $30 \mathrm{~min}$ at room temperature in $0 \cdot 1 \times$ SSC.

The sections were then dehydrated and coated with liquid photographic emulsion (Kodak-NTB2; diluted 1:1 with water; Kodak, Rochester, NY, USA). Slides were exposed for 21 days, developed in Dektol developer (Kodak) for $2 \mathrm{~min}$ and fixed in rapid fixer (Kodak) for $4 \mathrm{~min}$. Thereafter, tissues were rinsed in running water for $30 \mathrm{~min}$, counterstained with hematoxylin and rapidly dehydrated through graded concentrations of ethanol, cleared in toluene and coverslipped with Permount (Fisher Scientific, Montreal, Canada).

Quantitative analysis of hybridization signals was carried out using a Zeiss optical system coupled to a Macintosh computer image software (version 1.6 non FPU, W Rasband, NIH, USA). The optical density (OD) of the signal was measured under darkfield illumination at a magnification of $\times 25$. Areas covering the different uterine and vaginal compartments were digitized and submitted to densitometric analysis, yielding measurements of integrated OD (area $\times$ average OD) as previously described (Givalois et al. 1998). The OD of each compartment was then corrected for the background signal which was determined on a consecutive section which had been hybridized with the labeled sense probe.

\section{Results}

\section{Uterus}

In the uterus of sham-ovariectomized (intact) mice, the hybridization signal was detected on epithelial cells (both luminal and glandular), stromal cells as well as myometrial smooth muscle cells (Figs 1A and B and 2A). As observed by brightfield (Fig. 1A and B) and darkfield (Fig. 2A) light microscopy, the labeling was uniformly distributed throughout the different uterine compartments. No significant autoradiographic reaction was observed after hybridization with the labeled sense probe (Figs 1C and 2B). Seven days after ovariectomy, a marked atrophy of epithelial, stromal and smooth muscle cells (Figs 1D and 2C) was noted. At the longest time-interval studied (24 h), the different compartments appeared in the process of reorganization but with cells of smaller size than those observed in intact animals (Fig. 1E and F). Quantitative analysis of AR mRNA levels revealed that ovariectomy induced a decrease of approximately $18 \%$ in OD $(P<0 \cdot 01)$ in both luminal epithelial and glandular epithelial cells (Fig. 3). $\mathrm{E}_{2}$ administration to 7-day ovariectomized mice induced a significant increase in AR mRNA levels as early as $3 \mathrm{~h}$ after injection. Similar AR mRNA levels were measured at the two other time-intervals (12 and $24 \mathrm{~h}$ ).

In the stroma, a $23 \%$ decrease in the hybridization signal was observed 7 days after ovariectomy. AR mRNA levels were restored to the levels observed in intact mice at the earliest time-interval studied $(3 \mathrm{~h})$ and remained constant thereafter (Figs 1E, 2D and 3). In the myometrium, after ovariectomy, AR mRNA levels were depressed by $50 \%$ (Figs 1D, 2C and 3). Three hours after $\mathrm{E}_{2}$ administration, there was a $37 \%$ increase in AR mRNA levels as compared with the levels observed in ovariectomized mice. Complete restoration of AR mRNA levels in smooth muscle cells occurred at both the 12- and 24-h time-intervals (Figs 1F, 2D and 3).

\section{Vagina}

In the vagina of intact mice, the hybridization signal was detected in both epithelial and stromal cells, with a higher density of labeling over the epithelium (Figs 4A and 5A). In vaginal sections hybridized with the sense probe, only a 


\section{Luminal epithelium}

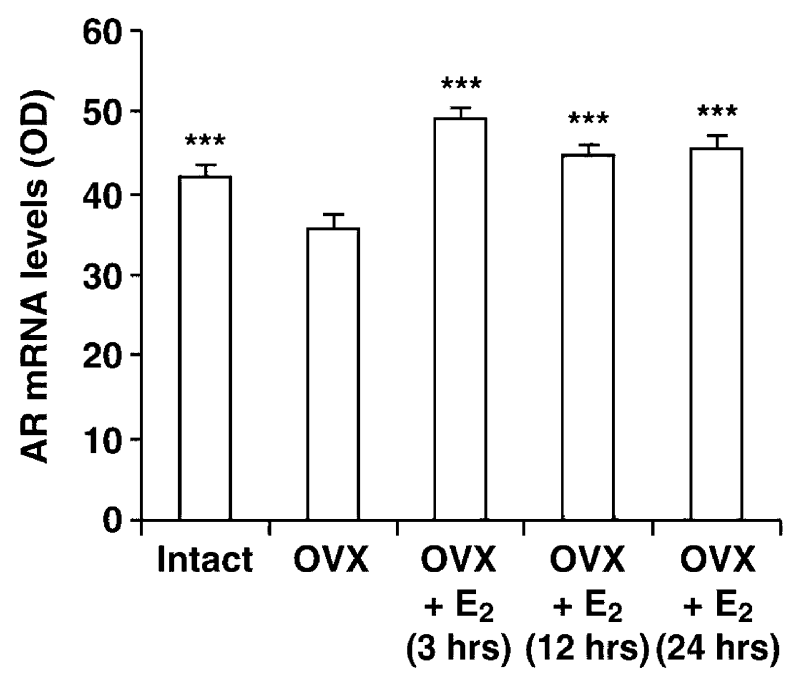

\section{Stroma}

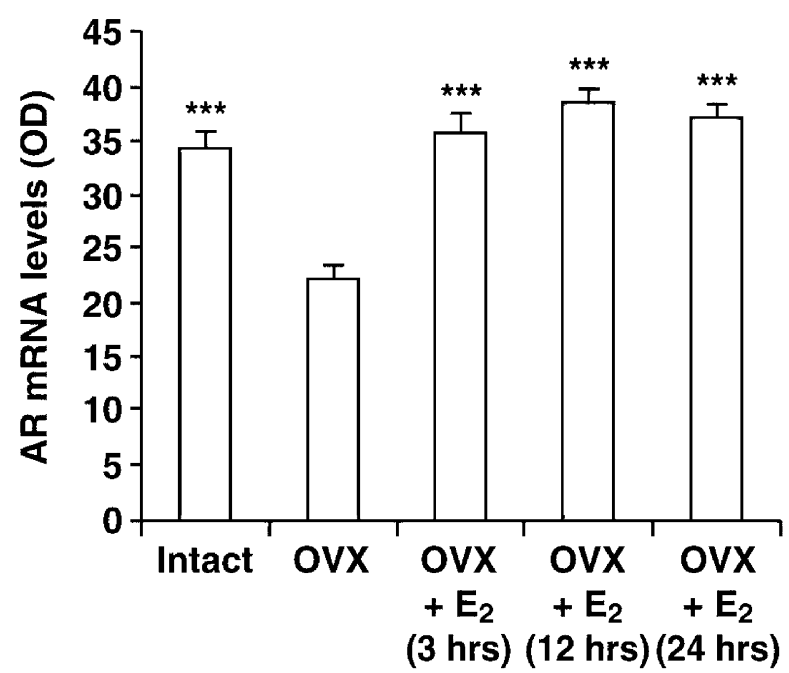

\section{Glandular epithelium}

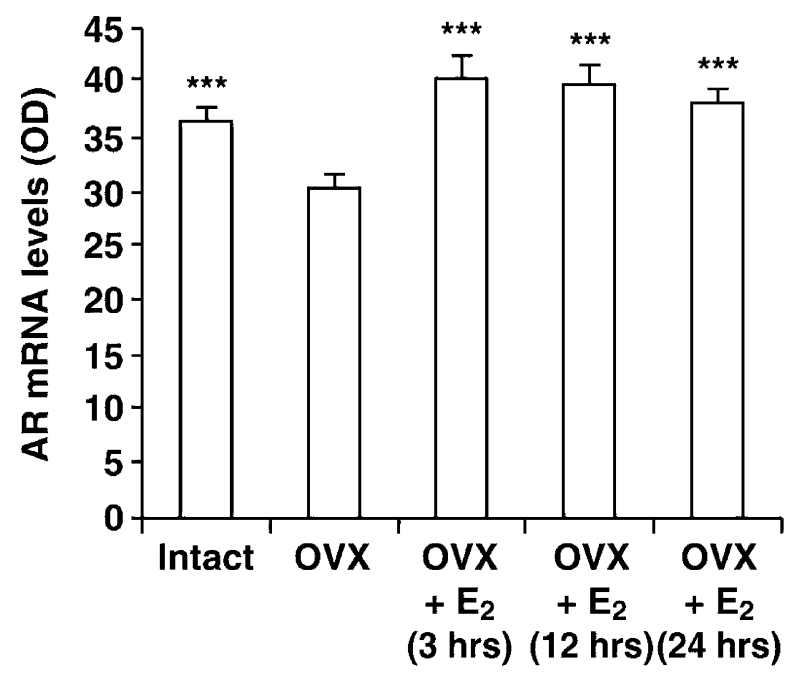

Myometrium

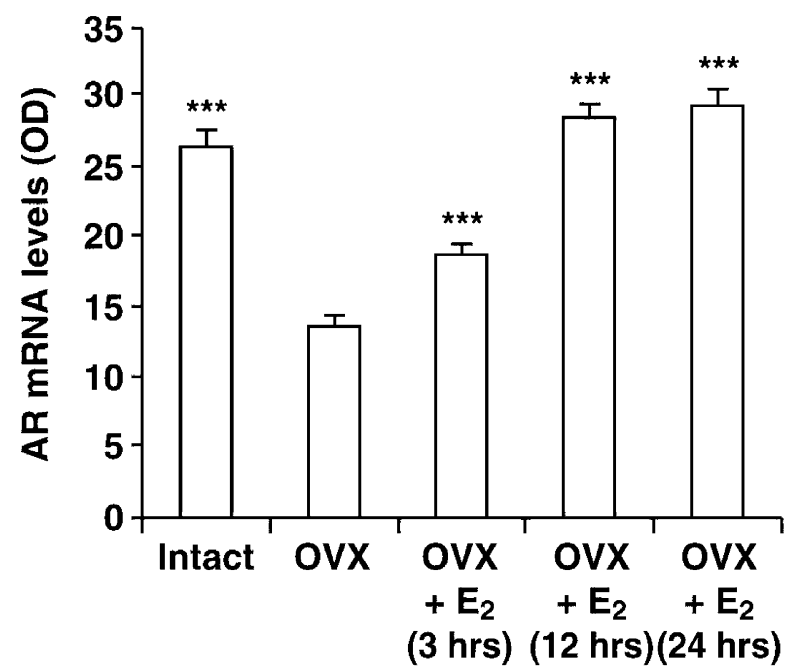

Figure 3 Mean \pm S.E.M. effects of ovariectomy and a single injection of $E_{2}$ to 7-day ovariectomized mice (OVX) on AR mRNA levels (OD) in the different uterine compartments. ${ }^{* *} P<0.001 \mathrm{Vs}$ OVX mice. The group of OVX mice which received $\mathrm{E}_{2} 3 \mathrm{~h}$ before they were killed is already significantly different from the group of intact mice $(P<0 \cdot 01)$.

weak and uniform labeling could be observed (Figs 4B and 5B). Seven days after ovariectomy, both the epithelium and stroma were markedly atrophied (Figs 4C and 5C). In the epithelium only atrophied cells probably belonging to the basal layer could be seen. Twelve and twenty-four hours after $\mathrm{E}_{2}$ administration, partial restoration of both epithelial and stromal compartments was observed, the epithelium height at the 24-h time-interval being clearly thicker than observed in ovariectomized animals.

In epithelial cells, ovariectomy induced a 30\% decrease in AR mRNA levels compared with levels measured in intact animals (Figs 4C, 5C and 6). No significant changes were observed $3 \mathrm{~h}$ after $\mathrm{E}_{2}$ administration. At longer time-intervals (12 and $24 \mathrm{~h}$ ), $\mathrm{E}_{2}$ induced an increase of 

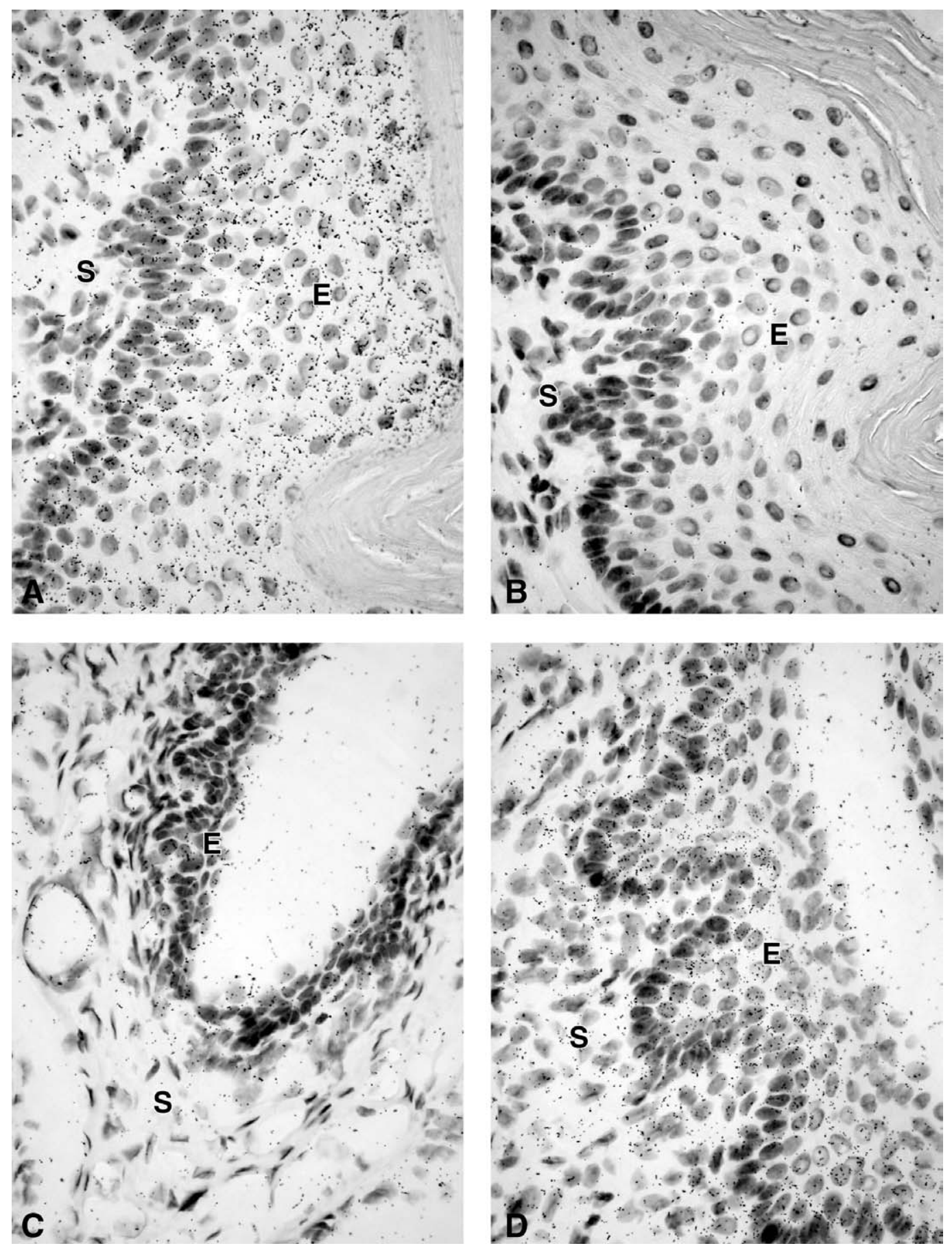

Figure 4 Representative brightfield micrographs illustrating the AR hybridization signal obtained in the mouse vagina. (A) Intact mice. (B) Section consecutive to that shown in (A) hybridized with the sense riboprobe (negative control). (C) Ovariectomized mice. (D) Ovariectomized mice which received a single injection of $\mathrm{E}_{2} 24 \mathrm{~h}$ before they were killed. E: epithelium; S: stroma $(\times 730)$.

approximately $125 \%$ in mRNA levels compared with ovariectomized mice (Figs 4D, 5D and 6). This increase corresponded to about $70 \%$ of the values observed in intact animals. In the stroma, ovariectomy induced a $55 \%$ decrease in AR mRNA levels (Figs 4C, 5C and 6). While no changes in AR mRNA expression were recorded at 

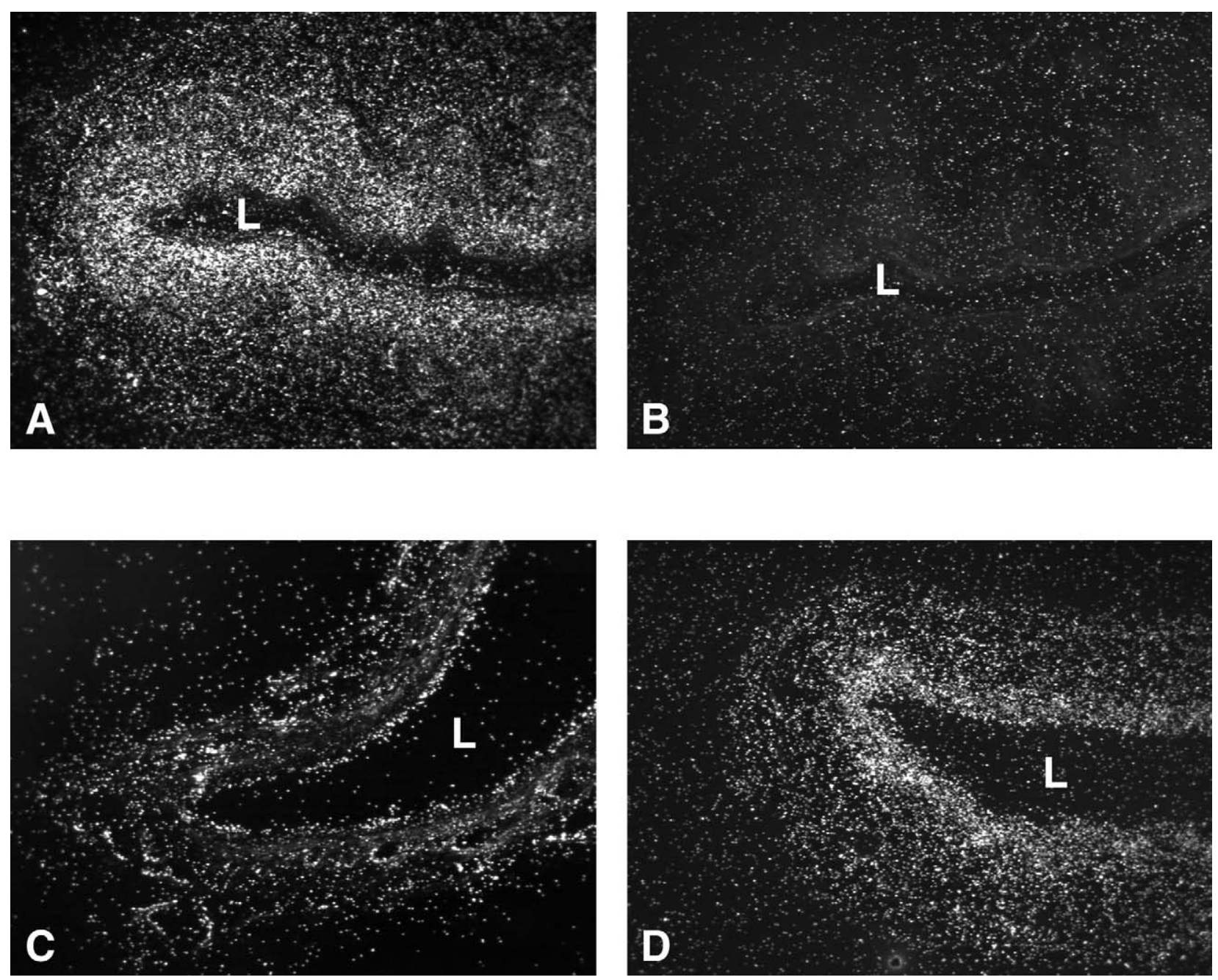

Figure 5 Representative darkfield micrographs showing AR mRNA expression in the mouse vagina. (A) Intact mice. (B) Section consecutive to that shown in (A) hybridized with the sense riboprobe (negative control). (C) Ovariectomized mice. (D) Ovariectomized mice which received a single injection of $\mathrm{E}_{2} 24 \mathrm{~h}$ before they were killed. L: lumen $(\times 13)$.

the 3-h time-interval, AR mRNA levels were completely restored at the longest time-intervals after $\mathrm{E}_{2}$ administration (12 and $24 \mathrm{~h}$ ) (Figs 4D, 5D and 6).

\section{Discussion}

The presence of AR mRNA in epithelial, stromal and smooth muscle cells in the mouse uterus confirms previous results obtained by immunocytochemistry in human, monkey and rat uterus (Kimura et al. 1993, Hirai et al. 1994, Adesanya-Famuyiwa et al. 1999, Pelletier 2000, Pelletier et al. 2000). It is noteworthy that, in the mouse uterus, the intensity of AR mRNA labeling is quite uniform throughout the different uterine compartments. In the monkey uterus, the expression of AR mRNA was lower in epithelial cells than in stroma or muscle cells (Adesanya-Famuyiwa et al. 1999).

The present data clearly demonstrated that, in all the compartments, AR mRNA levels were decreased by ovariectomy, the effect being more striking in the stroma and myometrium. AR mRNA levels were completely restored within $3 \mathrm{~h}$ in the epithelial and stromal cells and $12 \mathrm{~h}$ in the smooth muscle cells. These data indicated that estrogen can positively modulate AR mRNA levels in all the uterine compartments. It has been shown that administration of $E_{2}$ to ovariectomized monkeys for 3 days induced an increase in AR mRNA in endometrial stromal cells but not in the other uterine compartments (Adesanya-Famuyiwa et al. 1999).

In the uterus, estrogen receptor (ER)- $\alpha$ is the predominant ER (Kuiper et al. 1997, Couse et al. 2000) and has 


\section{Epithelium}

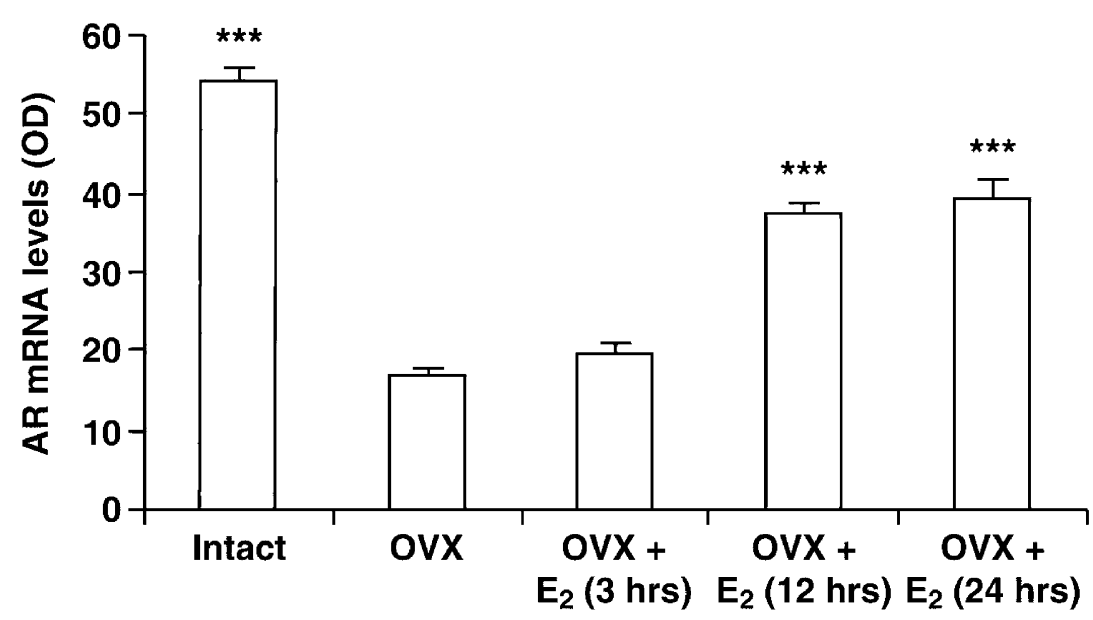

\section{Stroma}

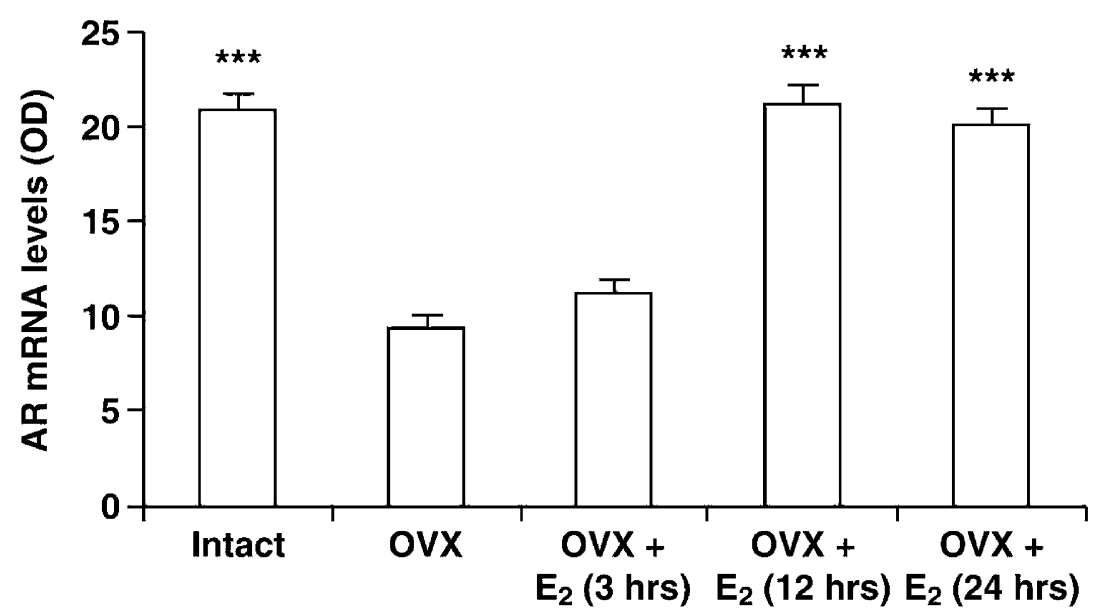

Figure 6 Mean \pm S.E.M. effects of ovariectomy and a single injection of $E_{2}$ to ovariectomized mice (OVX) on AR mRNA levels (OD) in vaginal epithelium and stroma. ${ }^{* * *} P<0 \cdot 001$ vs OVX mice.

been localized in the epithelial, stromal and smooth muscle cells (Couse et al. 2000, Pelletier 2000, Pelletier et al. 2000). In adult ER $\alpha$ knockout (KO) mice, a severe uterine atrophy is observed, while the uteri of ER $\beta \mathrm{KO}$ mice have a normal appearance and undergo the cyclic changes associated with ovarian hormones (Couse et al. 2000). It is, then, likely that the observed effects of $E_{2}$ on AR mRNA are mediated by ER $\alpha$.

The role of androgens in the regulation of uterine function is still unclear. It has been previously shown that estrogen can induce AR in the chick oviduct magnum mucosa (Tokarz et al. 1979). In immature hypophysectomized rats, the administration of testosterone or the non-aromatizable androgen dihydrotestosterone for 3 days can induce a marked increase in uterine weights (Armstrong \& Papkoff 1976). Very recently, Weihua et al. (2002) have shown that, in the immature rat uterus, $24 \mathrm{~h}$ after administration of $E_{2}$, there was an increase in the levels of $\mathrm{AR}$ and proliferation of luminal epithelial cells. Since the $\mathrm{E}_{2}$-induced proliferation of epithelial cells in the immature uterus was blocked by the pure antiandrogen flutamide, an involvement of androgens in the effect of estradiol on the uterus has been proposed (Weihua et al. 2002).

In the mouse vagina, we have observed that AR mRNA was expressed in both the epithelial and stromal 
cells, with a highest level of expression in the epithelial compartment. In the human vagina, AR was localized by immunocytochemistry in both epithelial and stromal cells (Hodgins et al. 1998, Pelletier 2000). In both mouse vaginal compartments, ovariectomy induced a marked depression in AR mRNA, while $\mathrm{E}_{2}$ induced a significant increase in AR mRNA at both 12- and 24-h timeintervals. These results clearly indicate a robust positive influence of circulating estrogens on the expression of AR mRNA. ER $\alpha$ is expressed in both epithelial and stromal cells in the mouse vagina (authors' unpublished observations). Moreover, in ER $\alpha \mathrm{KO}$ mice, but not in ER $\beta \mathrm{KO}$ mice, there is a marked vaginal hypoplasia and the vaginal tissue is insensitive to estradiol (Couse et al. 2000). These observations strongly suggest that, in the vagina, ER $\alpha$ is involved in the stimulatory influence of $\mathrm{E}_{2}$ on AR mRNA expression. The exact role of androgens in the development and function of the vagina remains to be fully explored.

In summary, the present data clearly showed that estrogens stimulate AR mRNA expression in both the uterus and vagina in adult mice. The effect is rapid, being observed within $3 \mathrm{~h}$ for the uterus and $12 \mathrm{~h}$ for the vagina after a single injection of $\mathrm{E}_{2}$ to 7-day ovariectomized mice, and is probably mediated through ER $\alpha$. In the uterus, AR could well be involved in the action of $\mathrm{E}_{2}$ in the different uterine cell types. The effect of ER $\alpha$ on the expression of the AR gene might be mediated by the AP-1 site since there are several AP-1 sites in the promoter region of the AR gene (Roy \& Chatterjee 1995).

\section{References}

Adesanya-Famuyiwa OO, Zhou J, Wu G \& Bondy C 1999 Localization and sex steroid regulation of androgen receptor gene expression in rhesus monkey uterus. Obstetrics and Gynecology 93 265-270.

Armstrong DT \& Papkoff H 1976 Stimulation of aromatization of exogenous and endogenous androgens in ovaries of hypophysectomized rats in vivo by follicle-stimulating hormone. Endocrinology 99 987-991.

Carson-Jurica MA, Schrader WT \& O'Malley BW 1990 Steroid receptor family: structure and functions. Endocrine Reviews $\mathbf{1 1}$ 201-234.

Clark JH, Schrader WT \& O'Malley BW 1992 Mechanisms of action of steroid hormones. In Textbook of Endocrinology, pp 35-90. Ed. J Wilson. Philadelphia: WB Saunders Company.
Couse JF, Curtis Hewitt S \& Korach KS 2000 Receptor null mice reveal contrasting roles for estrogen receptor alpha and beta in reproductive tissues. Journal of Steroid Biochemistry and Molecular Biology 74 287-296.

Evans RM 1988 The steroid and thyroid hormone receptor superfamily. Science 240 889-895.

Givalois L, Li S \& Pelletier G 1997 Age-related decrease in the hypothalamic CRH mRNA expression is reduced by dehydroepiandrosterone (DHEA) treatment in male and female rats. Molecular Brain Research 48 107-114.

Givalois L, Grinevich V, Li S, Garcia-de-Yebenes E \& Pelletier G 1998 The octadecaneuropeptide-induced response of corticotropin-releasing hormone messenger RNA levels is mediated by $\mathrm{GABA}_{\mathrm{A}}$ receptors and modulated by endogenous steroids. Neuroscience 85 557-567.

Hirai M, Hirata S, Osoda K, Hagibara K \& Kato J 1994 Androgen receptor mRNA in the rat ovary and uterus. Journal of Steroid Biochemistry and Molecular Biology 49 1-7.

Hodgins MB, Spike RC, Mackie RM \& MacLean AB 1998 An immunohistochemical study of androgen, estrogen and progesterone receptors in the vulva and vagina. British Journal of Obstetrics and Gynaecology 105 216-222.

Kimura F, Mizokami A, Oconuma T, Sasano H \& Nagura H 1993 Immunocytochemical localization of androgen receptor with polyclonal antibody in paraffin-embedded human tissues. Journal of Histochemistry and Cytochemistry 4 671-678.

Kuiper GGJM, Carlsson B, Grandien K, Enmark E, Haggblad J, Nilsson S \& Gustafsson JA 1997 Comparison of the ligand binding specificity and transcript tissue distribution of estrogen receptors $\alpha$ and $\beta$. Endocrinology 138 863-870.

Pelletier G 2000 Localization of androgen and estrogen receptors in rat and primate tissues. Histology and Histopathology 15 1261-1270.

Pelletier G, Labrie C \& Labrie F 2000 Localization of oestrogen receptor $\alpha$, oestrogen receptor $\beta$ and androgen receptors in the rat reproductive organs. Journal of Endocrinology 165 359-370.

Roy AK \& Chatterjee B 1995 Androgen action. Critical Reviews in Eukaryotic Gene Expression 5 157-176.

Ruizeveld de Winter JA, Trapman J, Vermey M, Mulder E, Zegers ND \& Van der Kwast TH 1991 Androgen receptor expression in human tissues: an immunohistochemical study. Journal of Histochemistry and Cytochemistry 39 927-936.

Tetsuka M, Whitelaw PF, Bremmer WJ, Millar MR, Smyth CD \& Hillier JG 1995 Developmental regulation of androgen receptor in rat ovary. Journal of Endocrinology 145 535-543.

Tokarz RR, Harrison RW \& Seaver SS 1979 The mechanism of androgen and estrogen synergism in the chick oviduct. Estrogen-modulated changes in cytoplasmic androgen receptor concentrations. Journal of Biological Chemistry 254 9178-9184.

Weihua Z, Ekman J, Almkvist A, Saji S, Wang L, Warner M \& Gustafsson JA 2002 Involvement of androgen receptor in 17 beta-estradiol-induced cell proliferation in rat uterus. Biology of Reproduction 67 616-623.

Received 10 July 2003

Accepted 4 September 2003 